Article

\title{
Variation in Immune-Related Gene Expression Provides Evidence of Local Adaptation in Porites astreoides (Lamarck, 1816) between Inshore and Offshore Meta-Populations Inhabiting the Lower Florida Reef Tract, USA
}

\author{
Joshua A. Haslun ${ }^{1}$, Briana Hauff-Salas ${ }^{2}$, Kevin B. Strychar ${ }^{3, *}$, James M. Cervino ${ }^{4}$ and Nathaniel E. Ostrom ${ }^{5}$ \\ 1 Lux Research Inc., Emerging Ecosystems in Agrifood and Health, 100 Franklin Street, 8th Floor, \\ Boston, MA 02110, USA; Joshua.Haslun@luxresearchinc.com \\ 2 Department of Math and Science, Our Lady of the Lake University, San Antonio, TX 78207, USA; \\ bhsalas@ollusa.edu \\ 3 Annis Water Resources Institute, Grand Valley State University, Muskegon, MI 49441, USA \\ 4 Department of Marine Chemistry, Woods Hole Oceanographic Institution, Woods Hole, MA 02543, USA; \\ jamescervino@gmail.com \\ 5 Department of Integrative Biology, Michigan State University, East Lansing, MI 48824, USA; \\ ostromn@msu.edu \\ check for \\ * Correspondence: strychak@gvsu.edu; Tel.: +1-616-331-8796
} updates

Citation: Haslun, J.A.; Hauff-Salas, B.; Strychar, K.B.; Cervino, J.M.; Ostrom, N.E. Variation in Immune-Related Gene Expression Provides Evidence of Local Adaptation in Porites astreoides (Lamarck, 1816) between Inshore and Offshore Meta-Populations Inhabiting the Lower Florida Reef Tract, USA. Water 2021, 13, 2107. https://doi.org/10.3390/w13152107

Academic Editor: José Luis Sánchez-Lizaso

Received: 4 June 2021

Accepted: 26 July 2021

Published: 31 July 2021

Publisher's Note: MDPI stays neutral with regard to jurisdictional claims in published maps and institutional affiliations.

Copyright: () 2021 by the authors. Licensee MDPI, Basel, Switzerland. This article is an open access article distributed under the terms and conditions of the Creative Commons Attribution (CC BY) license (https:// creativecommons.org/licenses/by/ $4.0 /)$.

\begin{abstract}
Coral communities of the Florida Reef Tract (FRT) have changed dramatically over the past 30 years. Coral cover throughout the FRT is disproportionately distributed; $>70 \%$ of total coral cover is found within the inshore patch reef zone $(<2 \mathrm{~km}$ from shore) compared to $30 \%$ found within the offshore bank reef zone ( $>5 \mathrm{~km}$ from shore). Coral mortality from disease has been differentially observed between inshore and offshore reefs along the FRT. Therefore, differences between the response of inshore and offshore coral populations to bacterial challenge may contribute to differences in coral cover. We examined immune system activation in Porites astreoides (Lamarck, 1816), a species common in both inshore and offshore reef environments in the FRT. Colonies from a representative inshore and offshore site were reciprocally transplanted and the expression of three genes monitored biannually for two years (two summer and two winter periods). Variation in the expression of eukaryotic translation initiation factor 3, subunit $\mathrm{H}(\mathrm{eIF} 3 \mathrm{H})$, an indicator of cellular stress in Porites astreoides, did not follow annual patterns of seawater temperatures (SWT) indicating the contribution of other stressors (e.g., irradiance). Greater expression of tumor necrosis factor (TNF) receptor associated factor 3 (TRAF3), a signaling protein of the inflammatory response, was observed among corals transplanted to, or located within the offshore environment indicating that an increased immune response is associated with offshore coral more so than the inshore coral $(p<0.001)$. Corals collected from the offshore site also upregulated the expression of adenylyl cyclase associated protein 2 (ACAP2), increases which are associated with decreasing innate immune system inflammatory responses, indicating a counteractive response to increased stimulation of the innate immune system. Activation of the innate immune system is a metabolically costly survival strategy. Among the two reefs studied, the offshore population had a smaller mean colony size and decreased colony abundance compared to the inshore site. This correlation suggests that tradeoffs may exist between the activation of the innate immune system and survival and growth. Consequently, immune system activation may contribute to coral community dynamics and declines along the FRT.
\end{abstract}

Keywords: Porites astreoides; patch reefs; coral bleaching; immunity; eIF3H; TRAF3; ACAP3

\section{Introduction}

Marine environments across the globe have been under rapid natural and anthropogenic change. One important consequence of rapid environmental change in marine 
environments has been increased occurrences of novel and previously lethal diseases [1-4]. As a result, keystone and foundational species have been extirpated including sea stars [5,6], oysters [7], shrimp [8], and corals [9] with many of these species expanding their ecological niches northward and southward toward the poles [10]. The loss of these species, however, can produce ecosystem level changes with wide ranging ecological, economic, and human health impacts. Researchers worldwide are rapidly trying to develop policies that identify and address marine epidemics, however non-lethal stress caused by microorganisms can also significantly affect populations. Surprisingly, little is known about the different ways non-lethal host-microbe interactions can affect and arise in marine invertebrate populations.

Ecological immunology [11,12] is a rapidly developing branch of evolutionary biology that seeks to identify why and how natural variation in immune response occurs across the biotic and abiotic landscape. More specifically, this branch of evolutionary biology provides insight into the susceptibility of organisms to parasitism or infection while incorporating the environmental constraints to an organism's physiological response. In circumstances where the environmental constraints on physiology are great, the depletion of resources following activation of the immune system may compromise an organism's capacity to respond to future stressors [13]. In this paper we built a case for local adaptation of the innate immune system of inshore vs. offshore populations of the coral Porites astreoides within the Florida Reef Tract (FRT), indicating the importance of understanding ecological immunity, especially within organisms challenged by the synergistic impacts of temperature and disease.

Increased frequency and severity of sea water warming events in conjunction with the increased prevalence and severity of coral disease are hypothesized to be the most significant contributing factors to coral community change along the FRT [14,15]. Over the past 30 years of such events, Porites astreoides has become increasingly dominant along the FRT as other previously dominant species (e.g., Acropora spp.) experience extirpation [14].

Porites astreoides displays several autecological traits that have been identified to contribute to increased survivorship along the FRT. First, among shallow ( $<2 \mathrm{~m}$ depth) nearshore reefs a green color morphology is more prevalent than the more common brown color morphology due to increased levels of a particular mycosporine-like amino acid (MAA), asterina-330 in the green morphotype, which confers increased resistance to ultraviolet radiation [16]. Second, in contrast to other coral species, Porites astreoides focuses breeding efforts during the more temperate spring season and some colonies remain gravid throughout the year. Such a reproductive strategy provides the host with ample opportunity to resupply energy stores after reproduction, increasing resistance to higher SWTs during summer months [17]. Third, Porites astreoides displays an inherent resistance to thermal stress [18]. Kenkel et al. [19] used gene expression to better understand acclimation and adaptation strategies to thermal stress in Porites astreoides. Resistance to thermal stress was primarily dependent upon the degree of prior exposure [20], and as a consequence, this species displays a wide habitat niche. Additionally, we have shown that the thermal stress response of colonies of Montastraea cavernosa, another common coral species of this region, is also dependent upon thermal history [21,22]. Therefore, we expect that the prior history of exposure to thermal stress affects acclimation and adaptation of other coral species as well. These data in addition to other reports support Porites astreoides as a generalist species with inherent resistance to stressors including elevated seawater temperatures SWT [23-27].

Despite its capacity for acclimating to heat stress, Porites astreoides experiences greater decreased growth rates in response to thermal stress variations [23]. That is, temperatures that fluctuate by more than one degree centigrade (i.e., at inshore reefs) over the course of one season vs. smaller incremental changes in temperature (i.e., offshore reefs) dictate growth rates in Porites astreoides [28]. Hence, increased thermal stress is more likely experienced by corals inhabiting inshore sites and healthier populations would be predicted at the offshore reefs. Contrary to this expectation, the abundance of Porites astreoides colonies 
and other species of corals is considerably lower at offshore sites of the FRT than at inshore sites of the FRT. Moreover, the mean colony diameter of this and other species at inshore reefs $(16 \mathrm{~cm})$ is half that of offshore reefs $(8 \mathrm{~cm})$ [28], and colonies $\geq 40 \mathrm{~cm}$ in diameter have only been reported among inshore reefs $[14,28]$.

Interestingly, the establishment of linkages between thermal stress and disease in corals have become common [29]. Frequency of diseases has been modeled across climate change scenarios [30,31]. In addition, differences in the annual local stress regime among coral reefs, in particular SWT, can contribute to the compromised state of corals [32]. Not only is the degree of the initial stressor important but a stress event can lead to an extended period of sensitivity and resource depletion. Coral bleaching, a decrease in the concentration of the symbiotic dinoflagellate, and/or symbiont pigments within the host can decrease fecundity and coral growth for more than one year [33].

Examples of adaptation or resistance to disease are less abundant than those presented for thermal stress, but occurrences have been reported. Colony-dependent differences in the resistance of Siderastrea siderea (Ellis and Solander, 1786) to dark spot syndrome have been observed in the Caribbean, and attributed to plasticity of the chemical defense [34]. Additionally, 6\% of Acropora cervicornis (Lamarck, 1816) colonies, which survived extirpation from the offshore bank-reef zone of the FRT as a result of "white" diseases [35,36], display resistance to the causative agent called white band disease. More recent work indicates that the disease tolerance of corals may be a result of differential activation of autophagy rather than cell death pathways in response to microbial stress [37]. Therefore, microbial stress has been a previous selective pressure within the region along with thermal stress. However, questions remain on how local adaptations can influence response to microbial stress.

The effects of elevated SWT do not appear to act as the only factor responsible for identified coral distributions in the FRT. Earlier studies that we conducted at reefs targeted in this work indicate the rarity of large offshore colonies ( $>30 \mathrm{~cm}$ diameter), which suggests an alternative stressor in lieu of increased SWTs [22], such as current, wave action, and/or genotypes or local adaptation. Biotic stress on the immune system from disease causing organisms, primarily bacteria, has severely impacted the FRT and is a likely contributing factor to the community differences among inshore and offshore reefs. Yellow band disease and dark spots disease are also common throughout the Caribbean and impact many corals including Porites astreoides [38-40]. The spread of each of these diseases has been linked to periods of increased thermal stress. Conversely, colder winter temperatures tend to diminish disease spread and reduce coral mortality by decreasing bacterial numbers and pathogenicity $[13,41,42]$. Therefore, lower winter temperatures effectively decrease the activation of the host immune response to biotic stress. The milder SWT regime of offshore bank reefs likely exacerbate disease related stress by failing to reduce the abundance of potential activators of disease during the winter (e.g., microbe abundance and pathogenicity).

Porites astreoides displays an increased capacity to resist thermal stress via gene regulation when increased thermal stress is more frequently experienced $[19,20]$. Inshore populations of Porites astreoides display increased colony growth during warmer SWTs than conspecifics inhabiting offshore reefs that experience less frequent thermal stress [23]. The colonies inhabiting the two habitats (inshore vs. offshore) also have different collective genotypes based on eight microsatellites [23], suggesting limited connectivity. Because gene flow can prevent local adaptation, genetic differentiation may be a requisite characteristic or alternatively, we speculate if difference occur because of plasticity.

Two hypotheses could explain the increased prevalence of hard corals at inshore sites compared to offshore sites despite lower levels of temperature stress offshore: (1) Larval recruitment rates are greater inshore resulting in an increased probability of recruit survival to adult stages; or (2) inshore coral populations are acclimatized or locally adapted to increased stress. Evidence to the contrary, regional differences in recruitment rate between the upper, middle, and lower FRT have been identified [43], and within a region, differences 
in local recruitment rates between inshore and offshore sites are similar [44]. Additionally, smaller Porites astreoides colonies $(<10 \mathrm{~cm}$ diameter) are prevalent along the inshore to offshore gradient independent of site, indicating efficient recruitment in both habitats. Therefore, the development of locally adapted populations of corals is far more likely to explain the unequal local distribution of corals along the FRT.

The objective of our study was to characterize the site-dependent expression of genes associated with the immune system and general stress response of Porites astreoides (Lamarck, 1816) over two seasons. Based on previous evidence, Porites astreoides populations within the FRT has a unique history that supports the development of locally adapted levels of immune response based on thermal history and disease occurrence. In this study, we reciprocally transplanted Porites astreoides colonies from an inshore patch reef and offshore bank reef and monitored the expression of three host specific genes associated with the innate immune system biannually for two years. Eukaryotic translation initiation factor 3, subunit $\mathrm{H}(\mathrm{eIF} 3 \mathrm{H})$ provided an indication of a general stress response, whereas tumor necrosis factor TNF receptor-associated factor 3 (TRAF3) and adenylyl cyclase-associated protein 2 (ACAP2) provided indications of activation of the immune system. The rational for picking these three genes is as follows. We chose to study eIF3H as it plays an important role in cell proliferation and ribosome production. TRAF3 was chosen as it plays a direct role in regulating both innate and adaptive immunity (in human models). We considered whether more TRAF3 would be upregulated stimulating faster immune responses when moved from one environment to another and then back to the original environment. ACAP2 was chosen as it "regulates/controls" the signaling cascade of immune responses and those made through time in host tissues. Collectively, these three molecules play and important role in the survivorship of a host organism. In this study, we questioned if Porites astreoides populations displayed unique or conserved responses to the stressors associated with inshore and offshore reef zones in order to identify potentially adaptive responses to the local environment.

\section{Materials and Methods}

\subsection{Materials Study Organism, Collection, and Preparation}

The two sites selected for this study, Birthday Reef (24.57917' N, -81.49692' W) and Acer24 Reef $\left(24.55268^{\prime} \mathrm{N},-81.43741^{\prime} \mathrm{W}\right)$, are representative of an inshore patch reef and offshore bank reef environment, respectively (Figure 1). The reefs are located adjacent to one another along Hawk Channel within the lower region of the Florida Keys National Marine Sanctuary (FKNMS). At both sites, reef communities are found at a similar depth $(6 \mathrm{~m})$. Inshore patch reefs of this region are characterized by greater abundance and diversity of scleractinian coral, increased variance in SWTs, and increased turbidity relative to the offshore reefs [22].

Since the objective of our study was to determine the site-dependent seasonal expression of genes associated with the immune system and general stress response of Porites astreoides (Lamarck, 1816) over two seasons, we chose winter (February) and summer (September), here, labeled as first summer (1st $S$ ) and winter (1st W) vs. second summer (2nd S) and winter (2nd W). To accomplish this goal Porites astreoides fragments from the inshore and offshore reefs were reciprocally transplanted. Fragments $\left(16 \mathrm{~cm}^{2} \times 16 \mathrm{~cm}^{2}\right)$ of Porites astreoides colonies $(n=6)$ were collected (NOAA National Marine Sanctuaries Permit \# FKNMS-2011-10) from each site at a depth of $6 \mathrm{~m}$ by divers using Self Contained Underwater Breathing Apparatus (SCUBA). A more detailed description of site construction methods is outlined in Haslun et al. [22] and Hauff-Salas et al. [45]. Each fragment at the transplant sites were sub-sampled bi-annually for two years during the summer (August-September) and winter (January-February) by divers equipped with SCUBA. During sub-sampling, a $2 \times 2 \mathrm{~cm}$ fragment was removed using a hack saw equipped with a tungsten carbide blade (Milwaukee CPO: Pasadena, CA, USA) to etch and cut into the fragment. Sampled fragments were placed into separate zip-lock bags and transported to the dive-boat for fixation. Fragments were rinsed with sterile sea water, wrapped in 
combusted tinfoil, and flash frozen in liquid nitrogen $\left(\mathrm{LN}_{2}\right)$. Processing from collection to fixation lasted less than $5 \mathrm{~min}$ for any single sample. Fixed samples were shipped to Michigan State University (East Lansing, MI, USA) and/or the Annis Water Resources Institute (Muskegon, MI, USA) on dry ice for further processing. All fragments were maintained at $-80^{\circ} \mathrm{C}$ at their given storage facility.

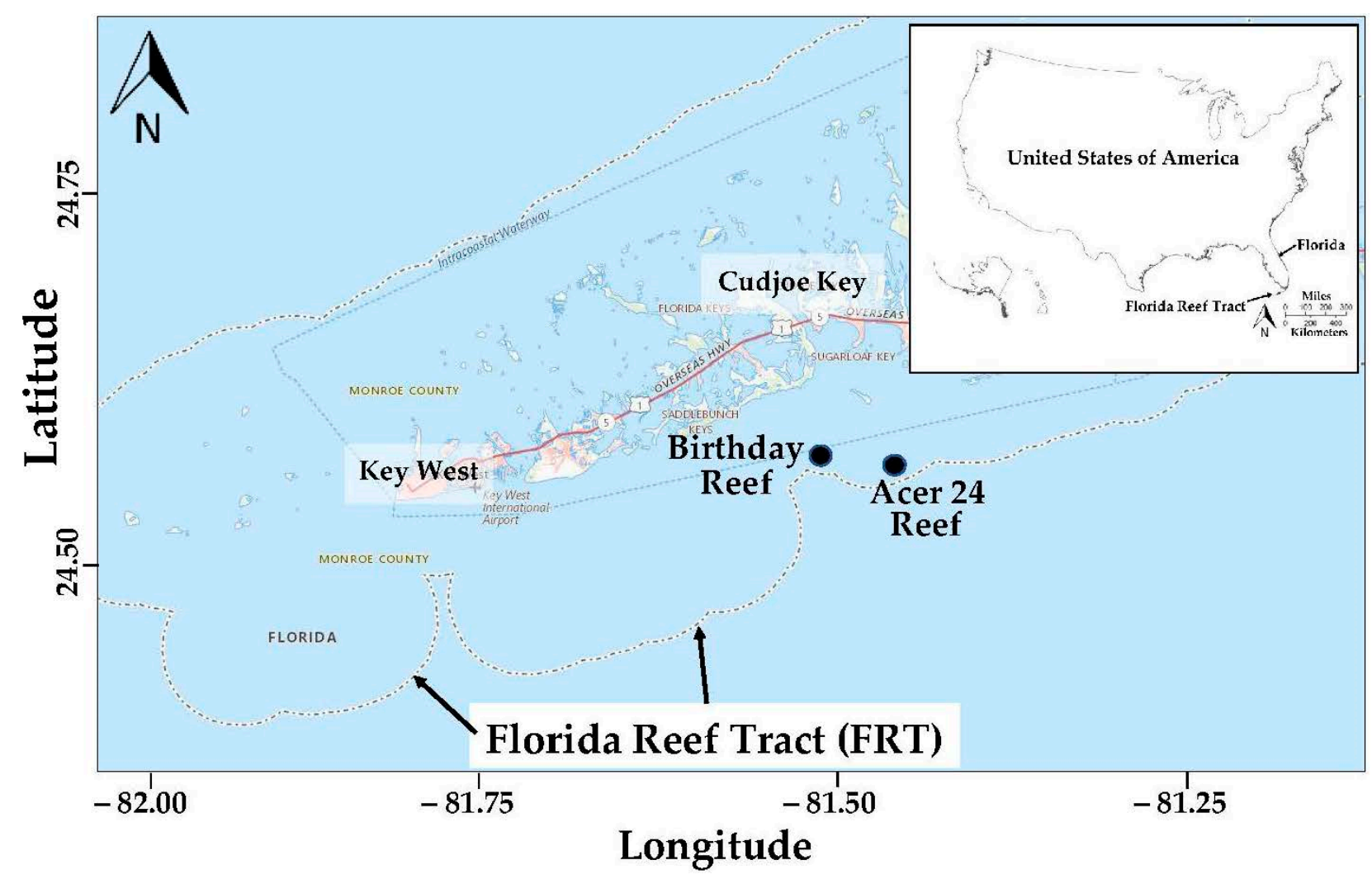

Figure 1. Insert (top right) shows the study site (black circle) located in the Florida Reef Tract (FRT) in Florida, USA. The lower FRT, located in the Florida Keys near Key West (USA) show the specific sample sites (larger figure). The inshore patch reef, Birthday Reef, is represented by a square and the offshore bank reef, Acer 24, reef is represented by a triangle.

\subsection{Sample Processing and RNA Isolation}

Coral fragments were processed as previously described [46]. Briefly, excess skeletal fragments were removed after first pulverizing fragments into smaller pieces in $\mathrm{LN}_{2}$ with a dounce-style stainless steel homogenizer, and the remaining tissue sample ground using a ceramic mortar and pestle. In order to prevent RNA degradation during grinding, samples were crushed in a shallow pool of $\mathrm{LN}_{2}$ within a chilled mortar and pestle. Mortar and pestles were cleaned between each using DI water and then $100 \%$ ethanol. The tissue powder was transferred to a microcentrifuge tube and stored at $-80{ }^{\circ} \mathrm{C}$ prior to RNA isolation.

RNA was isolated according to previously described methods [46] from $110 \mathrm{mg}$ of processed sample powder using a mixture of guanidine thiocyanate and phenol in a monophase solution (TRI Reagent: Sigma-Aldrich, St. Louis, MO, USA). Each RNA extraction was dissolved in $100 \mu \mathrm{L}$ of RNase and DNase-free water and integrity determined with a Caliper Lab Chip GX (Perkin Elmer: Waltham, MA, USA). RNA quality scores (RQS) greater than 6 were deemed of sufficient quality for two-step reverse transcription quantitative real-time polymerase chain reaction (qRT-PCR) [47]. RNA extraction yielded $\sim 2 \mu \mathrm{g}$ of RNA. 


\subsection{Reverse Transcription}

Isolated RNA was prepared for qRT-PCR by first treating $300 \mathrm{ng}$ of isolated RNA with 1 unit of DNase 1 (Life Technologies: Waltham, MA, USA) in accordance with the manufacturer's recommendations. From the treated sample, $260 \mathrm{ng}$ was reverse transcribed with the Superscript III first strand synthesis supermix (Life Technologies: Waltham, MA, USA). Reverse transcription reactions were carried out in a 96-well plate on an Eppendorf Mastercycler. The first-strand synthesis thermal profile was as follows: $10 \mathrm{~min}$ at $25^{\circ} \mathrm{C}$, $30 \mathrm{~min}$ at $50{ }^{\circ} \mathrm{C}, 5 \mathrm{~min}$ at $85^{\circ} \mathrm{C}$. After denaturation of the enzyme at $85^{\circ} \mathrm{C}, 1 \mu \mathrm{L}$ of $\mathrm{RNaseH}$ was added to each well and incubated at $37^{\circ} \mathrm{C}$ for $5 \mathrm{~min}$ to degrade the remaining template RNA.

Reaction components were removed from the cDNA product by the following previously described methods [46]. The resultant cDNA was stored at $-20^{\circ} \mathrm{C}$ for less than one week prior to qRT-PCR.

\section{4. qRT-PCR Primer Validation and Genes of Interest (GOI)}

Sequences of transcripts of interest were obtained from the Porites astreoides SymBioSys database (http:/ / sequoia.ucmerced.edu/SymBioSys / (accessed on 29 July 2021)). Primers were created with Primer3 [48] software applying the selection criteria outlined in Table 1. The top scoring primer pair was selected for qRT-PCR validation. Primer validation was performed by creating a standard curve relating the threshold cycle $(\mathrm{Cq})$ to the log concentration of cDNA along a 2-fold serial dilution; $5 \mathrm{ng} \mu \mathrm{L}^{-1}, 2.5 \mathrm{ng} \mu \mathrm{L}^{-1}, 1.25 \mathrm{ng} \mu \mathrm{L}^{-1}$, $0.625 \mathrm{ng} \mu \mathrm{L}^{-1}$, and $0.3715 \mathrm{ng} \mu \mathrm{L}^{-1}$ of cDNA. Primer pairs amplifying a single product according to dissociation curves displaying a highly linear relationship $(R 2>0.99)$ and adequate amplification efficiency $(3.0<\mathrm{E}<3.6)$ were considered valid for analysis (Table 2 shows genes of interest (GOI)).

Real-time PCR reactions were $10 \mu \mathrm{L}$ in volume. Each reaction included $1 \mu \mathrm{L}$ of template cDNA, $5 \mu \mathrm{L}$ of Power SYBR green master mix (Life Technologies: Waltham, MA, USA), $1.5 \mu \mathrm{L}$ of a primer pair (final concentration $250 \mathrm{nM}$ ), and $2.5 \mu \mathrm{L}$ DNase and RNase-free water. Amplification and detection of transcripts were analyzed on an Applied Biosystems 7900HT real-time PCR system in 384-well plate format following the manufacturer's recommendations. To prevent potential run-to-run variation and the need for inter-run calibrator samples, all samples were run in duplicate on a single 384-well plate for each gene of interest [49].

Table 1. Selection criteria for primers used to amplify transcripts for quantitative real-time polymerase chain reaction.

\begin{tabular}{cc}
\hline Primer Selection Parameter & Criteria \\
\hline Product size & $50-150$ \\
Number of results returned & 5 \\
Max repeat mispriming & 12 \\
Max template mispriming & 12 \\
Max 3' stability & 9 \\
Pair max repeat mispriming & 24 \\
Pair max template mispriming & 24 \\
Primer size & $18<20>22$ \\
Primer Tm & $57<59>61$ \\
Max Tm difference & 1 \\
Primer GC\% & $20<50>80$ \\
Max self-complementarity & 2 \\
Max \#'s & 0 \\
First base index & 1 \\
Max poly-X & 3 \\
Max-complementarity & 4 \\
\hline
\end{tabular}


Table 2. The amplification efficiency, primer sequences of each gene of interest (GOI), and control genes are presented in the table.

\begin{tabular}{|c|c|c|c|}
\hline Genes of Interest (GOI) & Abbreviation & Primer Sequence $\left(5^{\prime}-3^{\prime}\right)$ & Efficiency \\
\hline Adenylate cyclase associated protein 2 & ACAP2 & $\begin{array}{l}\text { F: TCGTCTGGAGTCTGCTGCT } \\
\text { R: TCTGCCACTTTGCCGTTTA }\end{array}$ & 2.04 \\
\hline Eukaryotic initiation factor 3 , subunit $\mathrm{H}$ & EIF3H & $\begin{array}{l}\text { F: TTGATTGATACCAGCCCACA } \\
\text { R: ACAAACTGCTTTGCTTTCCC }\end{array}$ & 1.97 \\
\hline TNF receptor-associated factor 3 & TRAF3 & $\begin{array}{l}\text { F: GTCTGGCTCCTCCCATCTTT } \\
\text { R: GCCTCCAGCATTCTAACCTG }\end{array}$ & 2.03 \\
\hline \multicolumn{4}{|l|}{ Control Genes } \\
\hline $\begin{array}{l}\text { 60S ribosomal protein } \\
\text { L11 }\end{array}$ & RPL11 & $\begin{array}{l}\text { F: TTTCAAGCCCTTCTCCAAGA } \\
\text { R: GACCCGTGCTGCTAAAGTTC }\end{array}$ & 1.94 \\
\hline Cathepsin L & CATL & $\begin{array}{l}\text { F: GGAAGGATTACTGGCTGGTC } \\
\text { R: GGATAGATGGCGTTTGTGG }\end{array}$ & 2 \\
\hline
\end{tabular}

\subsection{Genes of Interest (GOI)}

The protein tumor necrosis factor (TNF) receptor associated factor 3 (TRAF3) regulates the activation of immune responses along two pathways: (1) the myeloid differentiation primary response gene 88 (MyD88)-dependent pathway and (2) the toll interleukin receptordomain-containing adapter-inducing interferon- $\beta$ (TRIF)-dependent pathway [50-52]. Eukaryotic translation initiation factor 3 , subunit $\mathrm{H}(\mathrm{eIF} 3 \mathrm{H})$ regulate the translation of cytoplasmic mRNAs and degradation of proteins. Eukaryotic translation initiation factor 3 , subunit $\mathrm{H}(\mathrm{eIF} 3 \mathrm{H})$ is a component of the translation initiation complex formed by eIFs and contributes to the synthesis rather than degradation of proteins [53-56]. Adenylate cyclase associated protein 2 (ACAP2) interact with Ras, an intracellular membrane-bound protein, to regulate cyclic adenosine monophosphate (cAMP) production by adenylyl cyclase (AC) [57]. Ras is activated by transmembrane G-proteins that interact with external effector molecules to produce cAMP [58-60].

\section{6. qRT-PCR Analysis}

A Bayesian model-based approach [61] was applied to analyze qRT-PCR Cq data. Raw Cq values were transformed to molecular counts creating values with a linear rather than exponential relationship. A Markovian chain Monte Carlo generalized linear mixed model (MCMCglmm) with Poisson log-normal distribution was then applied. Applying an MCMC-based approach had several advantages over the traditional delta Cq methodology for this study [62]. First, it is rare that control genes behave perfectly stable in a natural setting. The MCMC-based approach allows for modeling of the variance associated with control genes and builds this error into the predictions. Secondly, this approach allows for the addition of random error terms that allow and correct for unequal template loading, resulting in normalization of the data. Thirdly, the hierarchical model produced allows for simultaneous determination of the treatment effects across all genes of interest (GOI) relative to control genes improving upon the gene-by-gene analysis applied with the delta Cq method [61].

We separated the analysis into two models a priori to identify transplantation sitedependent effects (Equation (1)) and collection site-dependent effects (Equation (2)). Molecular counts were the single response variable. The variable "gene" represented the different levels of expression associated with selected genes, "TransplantationSite" represented coral fragments grouped by where they were relocated to, "CollectionSite" represented coral fragments grouped by where they were collected from, "SeasonYear" represented the season by year combination (i.e., 1st S, 1st W). Conditions in brackets indicate random error terms and include the sample specific error, the gene specific sample error, and the gene specific error in the order presented in each model.

- $\quad$ Equation (1): 
count = gene + gene:TransplantationSite + gene:SeasonYear + gene:TranplantationSite:SeasonYear + [sample] + [gene:sample] + [gene:residual]

- $\quad$ Equation (2):

count = gene + gene:CollectionSite + gene:SeasonYear + gene:CollectionSite: SeasonYear + [sample] + [gene:sample] + [gene:residual]

Model parameters included 15,000 iterations, a thinning interval of 10, and sample size of 1000. A less-informative inverse Wishart prior with assumed variance of 1 and the degree of belief parameter at 0 was used for calculating variance components of all non-control genes. Control genes were allowed to vary on average 1.2-fold across the explanatory variables. Credible intervals ( $95 \%$ posterior probabilities) for fixed factors were calculated based on MCMC sampling.

\section{Results}

\subsection{Site Temperature Regime}

Temperature was monitored hourly at each site throughout the two-year transplant period (Table 3). Although the two sites displayed similar trends in SWT change as a function of season reflecting their close proximity (Figure 2A), their thermal ranges were significantly different.

Table 3. Seawater temperatures reported at the date of collection at the offshore site (Acer24 Reef) and the inshore site (Birthday Reef) are displayed in the table. The slope of temperature change during the week preceding sampling and $p$-value associated with the linear regression are also displayed. Note: first summer (1st $S$ ) and winter (1st W) vs. second summer (2nd S) and winter (2nd W) are shown. Asterisk indicate level of significance: ${ }^{*} \leq 0.05,{ }^{* *} \leq 0.01,{ }^{* *} \leq 0.001$; Significant values are in bold.

\begin{tabular}{|c|c|c|c|c|}
\hline Field Site & $\begin{array}{c}\text { Date } \\
\text { (Year-Month) }\end{array}$ & SWT at Collection $\left({ }^{\circ} \mathrm{C}\right)$ & One-Week SWT Slope & $\begin{array}{c}\text { Regression } \\
p \text {-Value }\end{array}$ \\
\hline \multirow[t]{4}{*}{ Acer24 Reef } & 1st W & 24.5 & 0.06592 & $0.0377 *$ \\
\hline & 1st $S$ & 30.6 & -0.08914 & 0.418 \\
\hline & 2nd $W$ & 22.9 & -0.49137 & $0.000467^{* * *}$ \\
\hline & 2nd S & 30.0 & -0.01571 & 0.513 \\
\hline \multirow[t]{4}{*}{ Birthday Reef } & 1st W & 25.2 & 0.19554 & $0.0024 * *$ \\
\hline & 1st $S$ & 31.5 & 0.04378 & 0.244 \\
\hline & 2nd $W$ & 22.0 & -0.59509 & $0.00115 * *$ \\
\hline & 2nd S & 30.3 & -0.05640 & 0.0765 \\
\hline
\end{tabular}

Seawater temperatures at Acer 24 remained lower during the summer and greater during the winter compared to those observed at Birthday Reef. During winter lows and summer highs, SWT differed by 0.5 to $1{ }^{\circ} \mathrm{C}$ between the sites. Additionally, the frequency of mean daily temperatures above $30^{\circ} \mathrm{C}$ was greater at Birthday than Acer 24 Reef. The eight days sampling preceding the 1 st $\mathrm{W}$ related to the period needed for activation/expression of these genes; seawater temperature increased significantly at Birthday Reef by $3{ }^{\circ} \mathrm{C}$ and at Acer 24 by $1{ }^{\circ} \mathrm{C}(p=0.0024, p=0.037$ respectively; Table 3). Conversely, during the following winter 2 nd $\mathrm{W}$ (winter), a significant decrease in temperature was observed at both sites during the eight days preceding sampling; $3{ }^{\circ} \mathrm{C}$ at Birthday Reef and $2{ }^{\circ} \mathrm{C}$ at Acer 24 ( $p=0.001$ and $p=0.000$, respectively; Table 3$)$. The magnitude of the temperature increase during the 1 st $\mathrm{W}$ was greater than that which occurred during the 2 nd $\mathrm{W}$ analysis. There were no significant changes in temperature during the summer months over the week preceding sampling. 

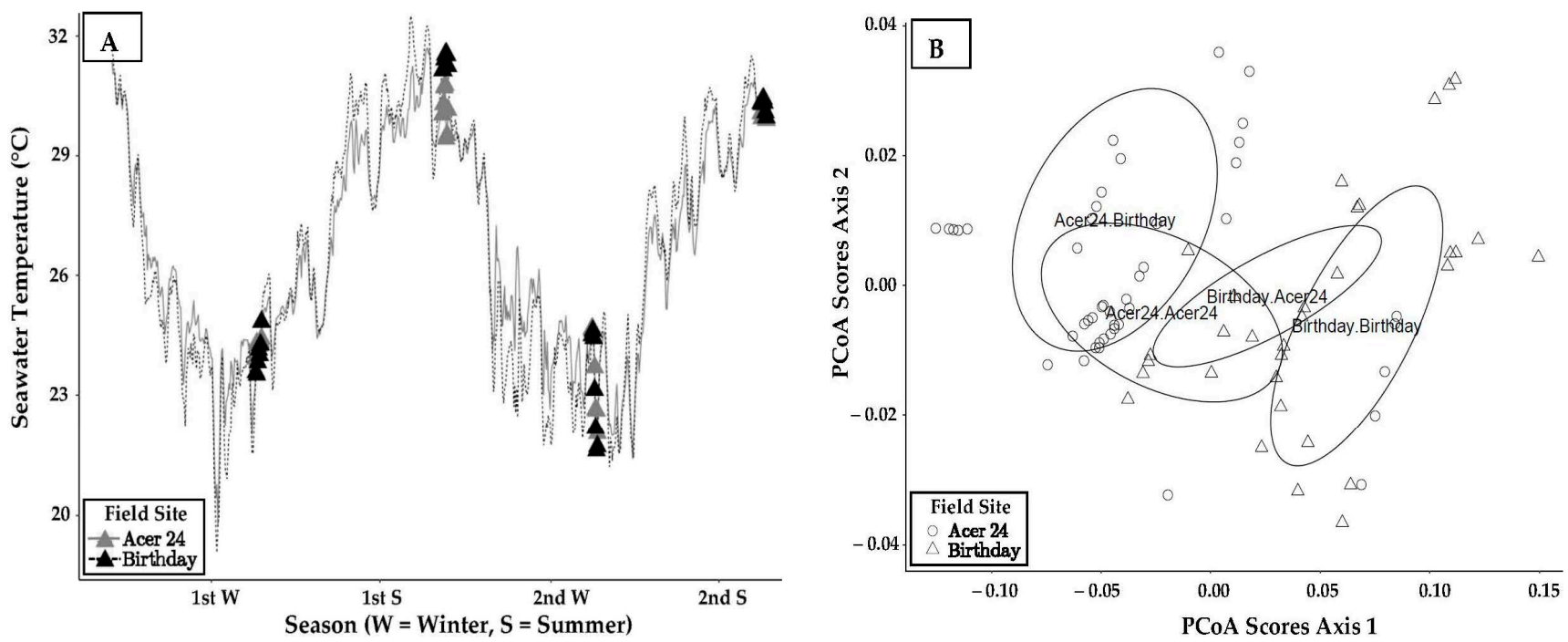

Figure 2. (A) Figure displays hourly water temperature for Birthday Reef (black triangle, black dotted line, inshore patch reef) and Acer 24 (gray triangle, gray solid line, offshore bank reef) over the course of a two-year reciprocal transplant experiment. Daily water temperature means are presented for the day of sampling for each of the four sample periods as well as the mean daily water temperatures for the previous 6 days prior to sampling corals at the Acer24 and Birthday Reef field site. Note: First summer (1st S) and winter (1st W) vs. second summer (2nd S) and winter (2nd W) are shown. (B) Principal coordinate analysis (PCA) results indicating a collection site-dependent effect on transcript abundance. Manhattan distances of transcript abundances were used to create the distance matrix. Axes 1 and 2 are plotted. The labels represent the mean of axis 1 and axis 2 for each group. Open circles indicate corals collected from Acer24 Reef and open triangles represent those collected from Birthday Reef.

\subsection{Effects of Site and Season on Pooled Genes of Interest (GOI) Transcript Abundance}

Markovian chain Monte Carlo generalized linear mixed model (MCMCglmm) analyses were performed to determine the effects of transplant (Table 4) and collection site (Table 5) on transcript abundance across all GOI. Both models converged to a stationary distribution with 15,000 iterations after given an initial 5000 iterations to dissipate extreme variation. Sampling every 10 iterations provided a total of 1000 sampling points from which to build credible intervals. Fragments originating from Acer 24 exhibited greater transcript abundance across all GOI than those originating from Birthday Reef $(p=0.010)$. This indicated a potential population level effect on gene expression. The site a fragment was transplanted to/from did not affect transcript abundance when GOI were collectively analyzed. Additional support for a collection site effect was provided by principal coordinate analysis (PCoA) of the Manhattan distances of transcript abundances among the GOI (Figure 2B). Samples formed clusters dependent on collection site rather than transplant site. The greatest dissimilarity between treatments was between fragments collected from Acer 24 and transplanted to Birthday Reef and those collected from Birthday Reef and transplanted back to Birthday Reef. A significant linear relationship was observed between the slope of SWT change associated with the eight days preceding sampling and the second PCoA axis $(p=0.005)$, while the temperature at the time of sampling was not correlated to either axis (Table 2). This observation indicates that SWT change contributed to the difference in expression between transplant treatments. 
Table 4. Two-way factorial mixed effects model for transplant site-dependent and seasonal effects on transcript abundance of Porites astreoides following reciprocal transplantation between an inshore patch reef (Birthday Reef) and offshore bank reef (Acer 24). The results for the three genes of interest (GOI) adenylate cyclase associated protein 2 (ACAP2), eukaryotic initiation factor 3 subunit $\mathrm{H}$ (eIF3H), and TNF receptor associated factor 3 (TRAF3) are presented. Comparisons have been made to transcript abundances of samples transplanted to Acer24 Reef and sampled during the 2ndW. Note: First summer (1st S) and winter (1st W) vs. second summer (2nd S) and winter (2nd W) are shown. Asterisks indicate level of significance: ${ }^{*} \leq 0.05,{ }^{* *} \leq 0.01,{ }^{* * *} \leq 0.001$; significant values are in bold.

\begin{tabular}{|c|c|c|c|c|c|}
\hline GOI & Comparison & Posterior Mean & Lower 95\% CI & Upper $95 \%$ CI & pMCMC \\
\hline \multirow[t]{7}{*}{ ACAP2 } & Birthday & -0.435 & -0.937 & 0.029 & 0.086 \\
\hline & 1 st W & -0.03757 & -0.49681 & 0.44522 & 0.926 \\
\hline & 1st $S$ & 0.019 & -0.372 & 0.5 & 0.938 \\
\hline & 2nd S & -0.14493 & -0.61418 & 0.36624 & 0.576 \\
\hline & Birthday: 1st W & 0.49994 & -0.21072 & 1.17273 & 0.132 \\
\hline & Birthday: 1st S & 0.40865 & -0.24205 & 1.04486 & 0.21 \\
\hline & Birthday: 2nd S & -0.30511 & -0.86000 & 0.25533 & 0.312 \\
\hline \multirow[t]{7}{*}{ eIF3H } & Birthday & -0.208 & -0.637 & -0.173 & 0.342 \\
\hline & 1 st W & -0.08121 & -0.50590 & 0.24429 & 0.7 \\
\hline & 1st $S$ & 0.34064 & -0.02892 & 0.7423 & 0.076 \\
\hline & 2nd S & -0.14893 & -0.59086 & 0.29031 & 0.508 \\
\hline & Birthday: 1st W & 0.06488 & -0.42012 & 0.68499 & 0.828 \\
\hline & Birthday: 1st S & -0.30511 & -0.86000 & 0.25533 & 0.312 \\
\hline & Birthday: 2nd S & 1.00556 & 0.43073 & 1.65886 & $<0.001 * * *$ \\
\hline \multirow[t]{7}{*}{ TRAF3 } & Birthday & 0.76547 & 0.15549 & 1.40063 & $0.010 *$ \\
\hline & 1 st W & 1.3774 & 0.73687 & 2.0328 & $<0.001 * * *$ \\
\hline & 1st $S$ & 1.80851 & 1.19198 & 2.48163 & $<0.001 * * *$ \\
\hline & 2nd S & 1.20155 & 0.50582 & 1.96071 & $<0.001 * * *$ \\
\hline & Birthday: 1st W & -0.60505 & -1.45238 & 0.40027 & 0.182 \\
\hline & Birthday: 1st S & -1.21753 & -2.07043 & -0.28946 & $0.008^{* *}$ \\
\hline & Birthday: 2nd S & -1.81851 & -2.85665 & -0.86877 & $<0.001 * * *$ \\
\hline
\end{tabular}

Table 5. Two-way factorial mixed effects model for collection site-dependent and seasonal effects on transcript abundance of Porites astreoides following reciprocal transplantation between an inshore patch reef (Birthday Reef) and offshore bank reef (Acer 24). The results for the three genes of interest (GOI) adenylate cyclase associated protein 2 (ACAP2), eukaryotic initiation factor 3 subunit $\mathrm{H}$ (eIF3H), and TNF receptor associated factor 3 (TRAF3) are presented. Comparisons have been made to transcript abundances of samples transplanted to Acer24 Reef and sampled during the 2nd W seasons. Note: First summer (1st S) and winter (1st W) vs. second summer (2nd S) and winter (2nd W) are shown. Asterisks indicate level of significance: ${ }^{*} \leq 0.05,{ }^{* * *} \leq 0.001$; significant values are in bold.

\begin{tabular}{cccccc}
\hline GOI & Comparison & Posterior Mean & Lower 95\% CI & Upper 95\% CI & pMCMC \\
\hline ACAP2 & Birthday & -1.147154 & -1.670249 & -0.666332 & $<.001 * *$ \\
& 1st W & -0.013090 & -0.446707 & 0.396193 & 0.958 \\
& 1st S & 0.277053 & -0.157765 & 0.713639 & 0.200 \\
& 2nd S & 0.119924 & -0.364999 & 0.552681 & 0.618 \\
& Birthday: 1st W & 0.394370 & -0.243777 & 1.033281 & 0.234 \\
& Birthday: 1st S & -0.193949 & -0.824670 & 0.472759 & 0.582 \\
& Birthday: 2nd S & 0.351856 & -0.372941 & 1.128164 & 0.374 \\
\hline eIF3H & Birthday & -0.586846 & -1.032692 & -0.112198 & $0.018 *$ \\
& 1st W & -0.266735 & -0.671877 & 0.103723 & 0.184 \\
& 1st S & -0.002953 & -0.389189 & 0.347585 & 1.000 \\
& 2nd S & 0.082943 & -0.337972 & 0.471331 & 0.678 \\
& Birthday: 1st W & 0.488955 & -0.150934 & 1.031597 & 0.108 \\
& Birthday: 1st S & 0.460195 & -0.172337 & 0.984013 & 0.124 \\
& Birthday: 2nd S & 0.839239 & 0.196500 & 1.522053 & $\mathbf{0 . 0 2 2} *$ \\
\hline
\end{tabular}


Table 5. Cont.

\begin{tabular}{cccccc}
\hline GOI & Comparison & Posterior Mean & Lower 95\% CI & Upper 95\% CI & pMCMC \\
\hline TRAF3 & Birthday & 0.362722 & -0.420370 & 1.282007 & 0.394 \\
& 1st W & 1.473018 & 0.761331 & 2.084224 & $<0.001 * * *$ \\
& 1st S & 1.666734 & 0.975813 & 2.272533 & $<0.001$ *** \\
& 2nd S & 0.614901 & -0.094805 & 1.261963 & 0.086 \\
& Birthday: 1st W & -0.852657 & -1.759411 & 0.160360 & 0.086 \\
& Birthday: 1st S & -0.985686 & -1.978128 & -0.025191 & 0.054 \\
& Birthday: 2nd S & -0.930772 & -1.904549 & 0.089161 & 0.072 \\
\hline
\end{tabular}

Transcript abundance differed between 2nd S and 2nd W for both the collection site $(p=0.012)$ and transplantation site $(p=0.008)$ models. Transcript abundances were lower during 2nd $S$ than the 2nd $W$.

\subsection{Specific Responses of the Genes of Interest (GOI)}

\subsubsection{TRAF3}

Porites astreoides fragments transplanted to Acer24 Reef displayed significantly greater transcript abundance than fragments transplanted to Birthday Reef ( $p=0.01$; Figure 3A). This difference was driven by increased transcript abundances during the 1st $S$ and 2 nd $S$ at Acer24 Reef compared to Birthday Reef ( $p<0.001$ for both comparisons). During the 1 st W TRAF3 gene expression was similar between the two reefs and reached comparable levels to those observed during each summer. During the Acer24 sampling periods, transcript abundances observed during each winter were less than those quantified the following summer, indicating a potential effect of season on TRAF3 expression at Acer24. This pattern was not observed at Birthday Reef. Instead, a significant difference in transcript abundance was only evident between the 1 st $W$ and the following 2 nd $S(p<0.001$; Figure $3 \mathrm{~A})$.

Although the collection site did not impact the expression of TRAF3, differences between sampling periods were observed. The transcript abundance observed during the 2nd $\mathrm{W}$ season of sampling was significantly lower than the expression observed during both the 1 st $W$ and 1 st $S$ sampling ( $p<0.001$ for each comparison). During a given sampling period collection site did not affect TRAF3 expression, unlike that observed for the site a coral was transplanted to.

\subsection{2. eIF3H}

The expression of eIF3H was significantly greater among corals collected from Acer24 compared to Birthday Reef site ( $p=0.018$; Table 5). This result was apparent despite the similarity in expression of eIF3H observed for all but one of the sampling periods, $2 \mathrm{nd} W$ $(p<0.022$; Figure 3B).

The site a coral fragment was transplanted to significantly affected the expression of eIF3H during summer months but not winter months (Figure 3B). During the 1st $S$ sampling, expression was greater for corals transplanted to Acer24 compared to Birthday Reef $(p<0.001)$ but this significant trend was reversed the following summer $(p<0.001)$.

\subsubsection{ACAP2}

Transcript abundances of ACAP2 were significantly affected by collection site $(p=0.0001$; Table 5). Corals collected from Acer24 displayed greater ACAP2 expression for each sampling period compared to corals collected from Birthday Reef (Figure 3C). This collection site-dependent effect on transcript abundance was not influenced by sampling period. Additionally, the site that a coral fragment was transplanted to did not affect ACAP2 transcript abundance. 


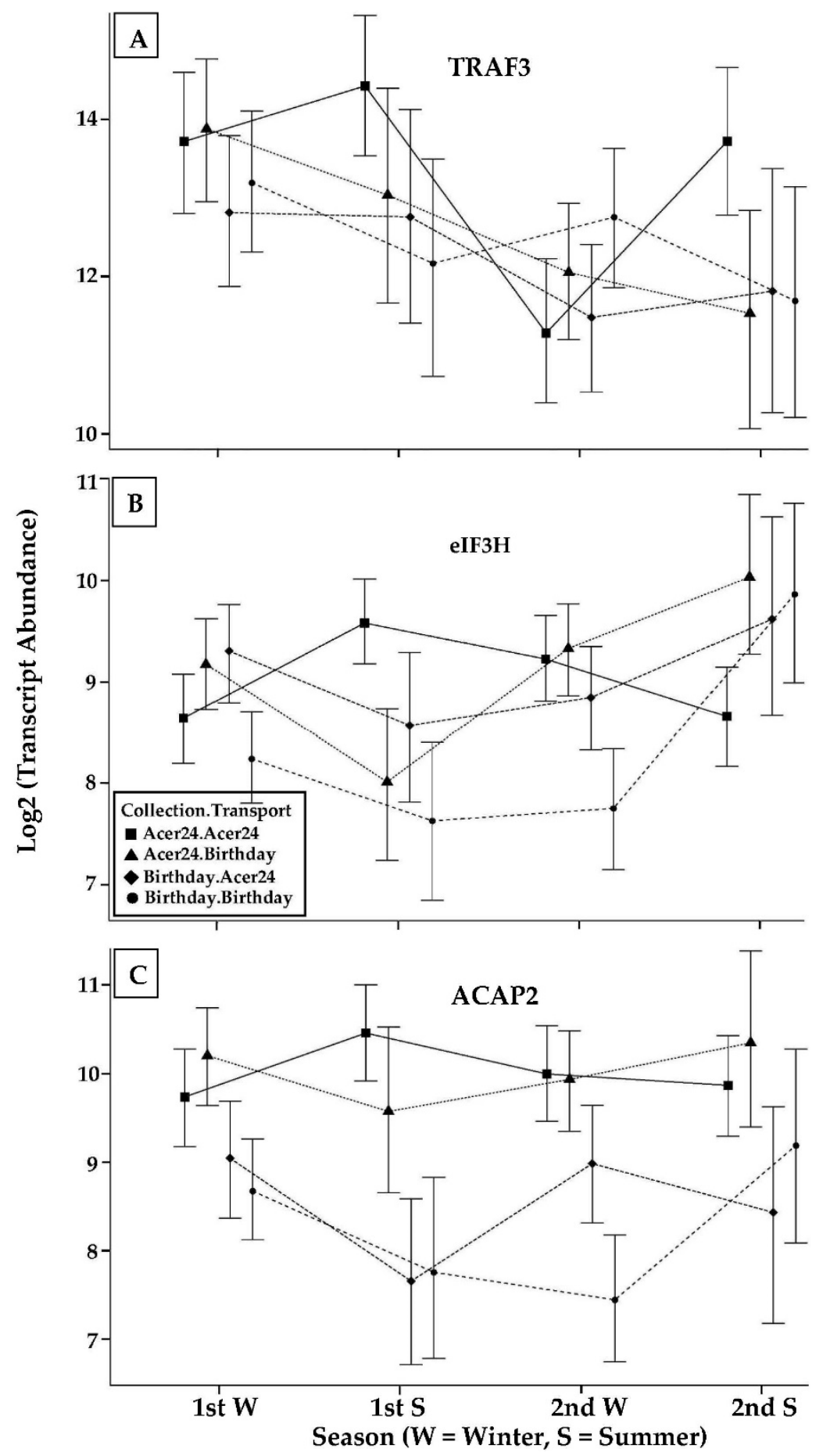

Figure 3. The log2 scaled abundances of (A) TRAF3, (B) eIF3H, and (C) ACAP2 transcripts from corals reciprocally transplanted between an inshore site (Birthday Reef) and an offshore site (Acer24). Samples were collected for analysis during the winter (February) and summer (September) seasons. Points represent the posterior means following MCMC generalized linear mixed modeling. Error bars indicate $95 \%$ credible intervals defined by the model. Note: First summer (1st S) and winter (1st W) vs. second summer (2nd S) and winter (2nd W) are shown.

\subsubsection{Summary of Factors Affecting Host Gene Expression in Porites astreoides}

Distinct patterns of transcript abundance were identified for each of the three GOI. The expression of TRAF3 differed between winter and summer but only for samples transplanted to Acer24. Significant transplant site-dependent effects were apparent in the 
expression of eIF3H during summer while a collection-site dependent effect was observed for ACAP2 across all sampling periods. We also observed that the direction and magnitude of the slope associated with the previous week of temperature change was a significant factor affecting gene expression while the previous days SWT during a given sampling event was not.

\section{Discussion}

\subsection{Activation of Host Coral Immune Pathways: TRAF3 Expression}

Along the FRT corals inhabiting offshore bank reefs display decreased growth and abundance (e.g., fitness) compared to corals inhabiting inshore patch reefs [22]. Although elevated SWTs are generally associated with decreased coral abundance (albeit other factors may also contribute such as strength of the currents), we speculate that higher SWTs and increased temperature variation are characteristic of inshore patch reefs to a greater extent than offshore. One possible explanation of this trend is that temperature indirectly affects the activation of the coral immune system by influencing the level of biotic stress (e.g., increased bacteria/viral levels) experienced by the coral (other possible explanations include changes in salinity, ocean acidification, UV radiation, turbidity, and even tourism). In this study, we suggest that the expression of genes associated with the activation of the innate immune system were environment-dependent, an adaptive response to environmentdependent biotic stressors. The role of each gene examined is discussed in turn to describe how SWT indirectly influences biotic stress level contributing to the observed differences in growth and abundance between the inshore and offshore sites.

The protein TRAF3 regulates the activation of the innate immune response along the MyD88 dependent and TRIF dependent pathways [50,51]. Both pathways are activated by the attachment of pathogen associated molecular patterns (PAMPs) to cell surface tolllike receptors [52,53]. Once activated, TRAF3 itself activates the production of effector molecules of the immune system that initiate inflammatory responses and interferon regulatory transcription factors that promote antiviral activity (i.e., type 1 interferon) [51]. Therefore, expression of TRAF3 provides an indication of the cumulative activation of the MyD88 and TRIF pathways, which in turn reflects the host's recognition of and response to bacterial and viral molecular patterns in the surrounding environment.

Our results indicate that it is not the site of origin that controls TRAF3 expression but rather the environmental conditions a coral host is currently exposed to. For this particular gene, we speculate that population dependent difference would be unlikely because tolllike receptors are conserved across animal phyla and activation occurs following the recognition of general rather than specific PAMPs (i.e., all bacterial lipopolysaccharides vs. species specific variants). The general and conserved nature of this pathway likely constrains selection on TLRs. The effect of local environment on TRAF3 expression was observed insofar as Porites astreoides transplanted to the offshore site displayed greater TRAF3 expression than those transplanted inshore. This difference in TRAF3 expression was driven by significantly greater expression at offshore sites compared to inshore sites during the summers $(p<0.001)$. Increased SWT is often directly linked to responsive physiological changes in corals. Contrary to this generalization, increased temperatures during the summers did not co-occur with increased TRAF3 activation. Instead, mean daily temperatures at the inshore site were on average $<1{ }^{\circ} \mathrm{C}$ those of the offshore site. In addition, greater variation between transplants was identified along the first principal coordinate and a relationship with SWT was not observed (Figure 3A). Therefore, environmental factors other than SWT must contribute to variation in TRAF3 expression along this primary axis. During the winters, however, increased TRAF3 expression was observed following a period of increasing SWT, whereas the lowest TRAF3 expression was observed following a period of decreasing SWT. Thus, cooling SWT during the winters, which reflect the inshore site SWT, was associated with less TRAF3 expression, whereas warming SWTs during the winter enhanced TRAF3 expression, a characteristic of the offshore site. 
The direct link between TRAF3 expression and the recognition of microbial derived molecular patterns through TLRs indicates that biotic stress may be an additional contributing factor in this environment-dependent effect. However, during winter periods, high SWT undoubtedly contributes to the level of biotic stress experienced $[63,64]$. Bacterial abundance decreases during the winter, but shorter and warmer winter seasons increase the proliferation as well as pathogenicity of microorganisms [21]. Because warmer SWTs increase the metabolic and growth rates of microorganisms [65,66], correspondingly many diseases affecting marine macroorganisms increase in prevalence including those affecting corals [67-69]. Not surprisingly, seasonal variation in temperature (i.e., winter vs. summer) has been identified as one of the most prominent factors controlling the rate of microbial growth $[70,71]$, with the greatest abundance of microbes observed in summer and lowest in winter [72]. Therefore, during warmer periods (summer), an increased abundance of foreign substances capable of binding TLRs is expected because of increase proliferation and pathogenicity of microorganisms. Conversely, cooler periods are expected to result in decreased biotic stress and subsequent TRAF3 expression. We identified both of these trends in TRAF3 expression: decreasing winter temperatures limited TRAF3 expression vs. warm periods consistent with the greatest levels of TRAF3 expression. Moreover, on an annual basis, temperature variation is greater at the offshore compared to the inshore site. However, according to the hypothesis laid out by Harvell et al. [15] and evidence supplied by others $[65,68,69]$, the offshore sites warmer winter SWT's alone fails to explain the accumulation of TLR compatible molecular patterns and the resulting activation of the immune system in the offshore relative to the inshore. Additionally, exposure of these same coral fragments from this study to increased temperature $\left(32{ }^{\circ} \mathrm{C}\right)$ and lipopolysaccharide $(5$ $\mu \mathrm{g} \mathrm{mL}^{-1}$ ) indicated that corals collected from offshore sites activated the innate immune system to a greater degree than the inshore sites [28]. Corals transplanted to the offshore site likely encountered more immune activating compounds and displayed significant upregulation of TRAF3 relative to the control treatment $\left(28^{\circ} \mathrm{C}\right)$, whereas response in offshore corals was similar to the control and significantly lower than that of the inshore site. Accordingly, corals that had experienced increased immune system activation inherent to the offshore site upregulated TRAF3, whilst those from the inshore site did not activate this response as greatly. Upregulation likely reflects increased exposure from the local environment. In this case, upregulation was experienced to a much greater degree in the offshore site.

The differential TRAF3 expression we observed in corals transplanted to inshore and offshore sites indicates local differences in the degree of immune system activation. Moreover, our results indicate that the degree of immune activation is linked to the SWT regime of a site. Lower winter SWT decreased immune system activation while the milder temperature regime of the offshore site increased activation. These temperature changes are undoubtedly linked to the abundance of PAMPs capable of activating the immune response. As such, we suggest that more work needs to be done identifying immune system proteins and pathways used by corals experiencing thermal and/or disease stressors and in various environments such as inshore and offshore reef habitats.

\subsection{Cellular Stress Response: eIF3H Expression}

Eukaryotic translation initiation factor 3, subunit $\mathrm{H}$ (eIF3H) is a component of the translation initiation complex formed by eIFs and therefore contributes to the synthesis rather than degradation of proteins [53]. This gene is upregulated in Porites astreoides during periods of stress [61]. During periods of stress, energetically consumptive processes in cells are moderated; however, upregulation of eIFs results in increased protein production that can counteract intracellular production of reactive compounds associated with metabolic dysfunction [55]. Increased activation of eIF3 genes has also been shown to decrease cellular stress levels from abiotic stress in transgenic yeast [56]. Upregulation of eIF3H is therefore an indication of stress and as such, is another important stress-related response protein in coral shown to respond to varying SWT (see $[19,20,73,74])$. 
Although we observed differential expression of eIF3H among corals transplanted to inshore and offshore sites during the summers, a consistent site-dependent effect on expression between summers was not observed. In fact, during 2012, eIF3H expression was greatest in corals transplanted to the inshore site, whilst during the following year corals transplanted to the offshore site displayed the greatest expression. Hence, our experimental design did not reveal any temperature-related stresses in either year. Based upon the similar SWTs and SWT variation at both sites prior to sampling, we anticipated corals from both sites to display similar expressions or that corals transplanted to the inshore site would be less impacted due to the larger variation in annual temperatures that these corals are accustomed to. Instead, corals from the inshore site displayed greater expression of eIF3H compared to the offshore site contradicting our expectations. Several factors may have contributed to the unexpected expression patterns of eIF3H. First, the temperature stress experienced during and prior to sampling may not have been sufficient to elicit a response driven by temperature. Second, eIF3H is likely to be activated by stressors in addition to temperature. Although cellular stress produced from elevated temperatures can be alleviated by increasing protein production, other potential reef stressors such as increased irradiance can produce intracellular stress conditions and alter eIF3H expression. Therefore, insightful applications of this gene may be more appropriate in laboratory settings, rather than in the field where environmental conditions cannot be controlled.

\subsection{Adaptive Response to Immune System Activation: ACAP2 Expression}

Through interactions with activated Ras proteins, adenylate cyclase-associated proteins (ACAPs) regulate the synthesis of cyclic adenosine monophosphate (cAMP) by adenylate cyclase (AC) [57]. Cyclic AMP is a second messenger effector molecule that induces the activation of proteins responsible for regulating many cell processes including growth, nutrient metabolism, temperature responses, and inflammatory responses $[75,76]$. When cAMP production is activated by Ras, stimulated via environmental cues, this molecule reduces the inflammatory response [60,75]; hence, ACAP2 reduces over-activation of the innate immune system.

Porites astreoides colonies collected from the offshore site expressed significantly greater levels of ACAP2 in all sampling periods relative to those collected from the inshore site (Figure 3C). This result was observed independent of transplant location, indicating that corals inhabiting the offshore site may be locally adapted to this environment. Local adaptation requires limited gene flow between populations along with intense selection on variation of a phenotype [76]. The broad dispersive reproduction strategy used by corals in addition to the long-lived nature of reef building corals has long been thought of as a barrier to local adaptation in the host animal. Wide dispersal facilitates consistent of low-level gene flow between metapopulations serves to increase diversity [77,78]. Although phenotypic diversity is necessary to produce local adaptation, diversity can also decrease the effect of selection pressure on a particular phenotype [79]. For instance, in our study, significant collection site-dependent differences in ACAP2 expression suggest local adaptation. Supporting our assumptions, Kenkel et al. [20,23] observed very little gene flow between inshore and offshore populations of Porites astreoides inhabiting the FRT. Similarly, Hauff-Salas et al. [46] observed collection site-specific responses in the zooxanthellae.

Local adaptations confer fitness advantages to an organism that is confronted with a hostile environment. We have previously established, based on increased expression of TRAF3 due to TRL recognition by foreign substances, that the offshore environment results in increased activation of the coral host's immune response relative to the inshore. Our results indicate that the offshore environment exposes corals to increased biotic stresses. Acute and chronic inflammatory responses act to the detriment of the host by decreasing fitness. For example, inoculation of the mealworm beetle, Tenebrio molitor (Linnaeus, 1758), with non-lethal levels of bacteria has been shown to decrease longevity [80]. Moreover, individuals of Tenebrio molitor that produce elevated levels of melanin, a critical molecule in the invertebrate innate immune response, have decreased longevity even without external 
stimulation [81]. Thus, reducing overactive or continuously activated immune responses may confer an advantage to the host. TRAF3 expression (i.e., an inflammatory response) was greatest among coral fragments transplanted offshore, which provides compelling evidence for an environmental adaptive response and immune system stimulation.

Organisms must allocate resources to all cellular processes from a finite supply; thus, immune responses come with a resource cost [82]. It is common to observe tradeoffs (i.e., principle of allocation), in which the expression of an adaptive trait increases while the expression of another trait or traits decreases. Tradeoffs resulting from adaptive responses to the innate immune system are more commonly detected in higher level traits such as survival, growth, longevity, and fecundity $[4,82]$ because of the difficulties inherent to observing the interactions between lower level traits. Coral species inhabiting the offshore reefs of the FRT, including Porites astreoides, display both a decreased mean colony size as well as decreased abundance relative to the populations inhabiting inshore reefs [22]. Porites astreoides colonies originating from the offshore sites in our study averaged $7.34 \mathrm{~cm}$ in diameter while those inhabiting the inshore site were $11.44 \mathrm{~cm}$ in diameter [22]. A decrease in the rate of skeletal linear extension is likely to be a high-level fitness tradeoff associated with diverting resources to both an active immune response and counteraction of that immune response. Similarly, Porites astreoides colonies inhabiting an adjacent offshore site have been shown to display decreased growth following exposure to stress relative to corals collected from an inshore reef [23].

Our results indicate that the activation of the immune response has affected population dynamics of Porites astreoides in two ways. First, in offshore coral, biotic activators of the immune system are likely to have decreased survival in Porites astreoides at some stage of ontogeny. It is likely that selection occurred at early stages as we observed growth of transplanted colonies throughout experiments (pers. obs.). Further, if unfit corals had reached maturation there would have been a decrease in selection pressure and a potential for diversity to increase. Selection pressure early in ontogeny may therefore contribute to decreased offshore coral abundance [28]. Second, the response of the host to activate the immune system at offshore sites likely resulted in an opposing adaptive response and decreased host growth rates. Although there is no doubt that climate related changes in abiotic factors (e.g., SWT) act to the detriment of corals and may also contribute to local adaptation, the interaction of abiotic and biotic stressors is important and should be considered in future studies. A detailed understanding of the contribution of the coral host's immune response, be it innate or other, may be especially important along reefs that have been drastically impacted and continue to be impacted by disease, such as the FRT [83-85].

\section{Conclusions}

Our study shows that activation of the immune system in Porites astreoides differs between an adjacent inshore and offshore reef. Colonies that were transplanted offshore expressed TRAF3 more than colonies that were transplanted inshore. Activation of TRAF3 occurs following recognition of foreign substances by TLRs, and therefore increased expression is likely a result of increased stress brought-on from biotic sources (i.e., bacteria/viruses) and/or stressed zooxanthellae. For instance, Hauff-Salas et al. [46] showed that offshore zooxanthellae were more stressed in offshore habitats responding to higher irradiance levels than those inshore. As a consequence, host coral likely recognize such stress and possibly considers the symbiont "foreign". Porites astreoides originating from the offshore environment also displayed increased expression of ACAP2 independent of any transplantation, an indication of local adaptation to stress. Because increased expression of the immune system results in fitness tradeoffs, this particular adaptation may be an effort by host corals to enhance survival by depressing activation of the immune response brought-on by the offshore environment. Porites astreoides inhabiting the offshore reef not only activated their immune pathways but also regulated this response by expressing ACAP2. While this likely enhances survival, it limits resource availability for other 
traits such as growth. Offshore bank reefs throughout the FRT currently exhibit decreased mean colony size and decreased abundance relative to the inshore and our study provides evidence of a link between increased immune responses and fitness.

In our study, increased immune system activation was associated with decreased SWT variation. Offshore sites displayed a milder temperature regime compared to inshore sites. Because lowest TRAF3 expression was observed during a period of decreasing winter SWTs, lower winter temperatures may decrease the activation of the immune system by limiting sources of biotic stress. As climate warming continues, winter low temperatures will likely increase placing biotic stress on inshore reefs and further exacerbate warming at offshore reefs [86]. The resulting increase in immune system activation may place resource constraints on a coral's ability to resist abiotic stressors and result in more severe bleaching events than currently occurs. It should be noted, however, that immune responses are generally associated with a host of multiple genes and sets of systems each controlling and contributing to different individual responses. In this study, we focused on 3 genes, however, these do not represent a complete picture of the immune response of an individual coral. This is clear in our results where some of the genes were activated and others were not. As such, future studies should focus on as many genes as possible per individual response, or key genes known to trigger a particular immune response.

Author Contributions: Conceptualization, J.A.H., K.B.S.; methodology, J.A.H., K.B.S., B.H.-S.; validation, J.A.H., K.B.S., B.H.-S.; formal analysis, J.A.H., B.H.-S.; investigation, J.A.H., K.B.S., B.H.-S.; resources, J.A.H., K.B.S., B.H.-S., J.M.C., N.E.O.; data curation, J.A.H., K.B.S., B.H.-S.; writingoriginal draft preparation, J.A.H., K.B.S., N.E.O.; writing-review and editing, J.A.H., K.B.S., B.H.-S., N.E.O.; visualization, J.A.H., K.B.S., B.H.-S., J.M.C., N.E.O.; supervision, K.B.S., N.E.O.; project administration, K.B.S., N.E.O.; funding acquisition, K.B.S., J.M.C., N.E.O. All authors have read and agreed to the published version of the manuscript.

Funding: We thank the Annis Water Resources Institute for both a graduate fellowship and research funding associated with this project, and Grand Valley State University for a Presidential Research Grant. We thank Michigan State University RTSF and the Integrative Biology Department at Michigan State University (Graduate Fellowship), and the Coastal Preservation Network (Award 250542). We also thank Erich Bartels and the Mote Marine Tropical Research Laboratory staff for their help with field and laboratory help and Jeff Landgraf for qRT-PCR help. This work could not have been completed without the help of the staff at Florida Keys National Marine Sanctuary (FKNMS) for providing permit number FKNMS-2011-10 allowing this research to take place.

Institutional Review Board Statement: Not applicable.

Informed Consent Statement: Not applicable.

Data Availability Statement: Not applicable.

Acknowledgments: The authors wish to express their gratitude to the editor and the reviewers for their valuable comments and assistance in revising the manuscript.

Conflicts of Interest: The authors declare no conflict of interest.

\section{References}

1. Burge, C.A.; Eakin, C.M.; Friedman, C.S.; Froelich, B.; Hershberger, P.K.; Hofmann, E.E.; Petes, L.E.; Prager, K.C.; Weil, E.; Willis, B.L.; et al. Climate change influences on marine infectious diseases: Implications for management and society. Ann. Rev. Mar. Sci. 2014, 6, 249-277. [CrossRef] [PubMed]

2. Groner, M.L.; Maynard, J.; Breyta, R.; Carnegie, R.B.; Dobson, A.; Friedman, C.S.; Froelich, B.; Garren, M.; Gulland, F.M.D.; Heron, S.F.; et al. Managing marine disease emergencies in an era of rapid change. Philos. Trans. R. Soc. B Biol. Sci. 2016, 371, 20150364. [CrossRef]

3. Aeby, G.S.; Shore, A.; Jensen, T.; Ziegler, M.; Work, T.; Voolstra, C.R. A comparative baseline of coral diesease across the central Red Sea. bioRxiv 2021. preprint. [CrossRef]

4. Howells, E.J.; Vaughan, G.O.; Work, T.M.; Burt, J.A.; Abrego, D. Annual outbreaks of coral disease coincide with extreme seasonal warming. Coral Reefs 2020, 39, 771-781. [CrossRef]

5. Hewson, I.; Button, J.B.; Gudenkauf, B.M.; Miner, B.; Newton, A.L.; Gaydos, J.K.; Wynne, J.; Groves, C.L.; Hendler, G.; Murray, M.; et al. Densovirus associated with sea-star wasting disease and mass mortality. Proc. Natl. Acad. Sci. USA 2014, 111, 17278-17283. [CrossRef] [PubMed] 
6. Lloyd, M.M.; Pespeni, M.H. Microbiome shifts with onset and progression of sea star wasting disease revealed through time course sampling. Sci. Rep. 2018, 8, 16476. [CrossRef]

7. Aalto, E.A.; Lafferty, K.D.; Sokolow, S.H.; Grewelle, R.E.; Ben-Horin, T.; Boch, C.A.; Raimondi, P.T.; Bograd, S.J.; Hazen, E.L.; Jacox, M.G.; et al. Models with environmental drivers offer a plausible mechanism for the rapid spread of infectious disease outbreaks in marine organisms. Sci. Rep. 2020, 10, 5975. [CrossRef] [PubMed]

8. Behringer, D.C.; Duermit-Moreau, E. Crustaceans, one health and the changing ocean. J. Invertebr. Pathol. 2020, in press. [CrossRef] [PubMed]

9. Precht, W.F. Failure to respond to a coral disease epizootic in Florida: Causes and consequences. Rethink. Ecol. 2021, 6, 1-47. [CrossRef]

10. Strychar, K.B.; Sammarco, P.W. Temperate Marine and Brackish Ecosystems. In Climate Change and Non-infectious Fish Disorders (CCNFD); Woo, P.T.K., Iwama, G.K., Eds.; CAB International: Wallingford, UK, 2020; pp. 1-24. ISBN 978-1786393982.

11. Sheldon, B.C.; Verhulst, S. Ecological immunology: Costly parasite defences and trade-offs in evolutionary ecology. Trends Ecol. Evol. 1996, 11, 317-321. [CrossRef]

12. Hawley, D.M.; Altizer, S.M. Disease ecology meets ecological immunology: Understanding the links between organismal immunity and infection dynamics in natural populations. Funct. Ecol. 2011, 25, 48-60. [CrossRef]

13. Nicholson, L.B. The immune system. Essays Biochem. 2016, 60, 275-301. [CrossRef]

14. Lirman, D.; Fong, P. Is proximity to land-based sources of coral stressors an appropriate measure of risk to coral reefs? An example from the Florida Reef Tract. Mar. Pollut. Bull. 2007, 54, 779-791. [CrossRef]

15. Harvell, C.D.; Mitchell, C.E.; Ward, J.R.; Altizer, S.; Dobson, A.P.; Ostfeld, R.S.; Samuel, M.D. Climate warming and disease risks for terrestrial and marine biota. Science 2002, 296, 2158-2162. [CrossRef] [PubMed]

16. Gleason, D.F. Differential effects of ultraviolet radiation on green and brown morphs of the Caribbean coral Porites astreoides. Limnol. Oceanogr. 1993, 38, 1452-1463. [CrossRef]

17. Chornesky, E.A.; Peters, E.C. Sexual reproduction and colony growth in the scleractinian coral Porites astreoides. Biol. Bull. 1987, 172, 161-177. [CrossRef]

18. Thomas, L.; Rose, N.H.; Bay, R.A.; López, E.H.; Morikawa, M.K.; Ruiz-Jones, L.; Palumbi, S.R. Mechanisms of thermal tolerance in reef-building corals across a fine-grained environmental mosaic: Lessons from Ofu, American Samoa. Front. Mar. Sci. 2018, 4, 434. [CrossRef]

19. Kenkel, C.D.; Aglyamova, G.; Alamaru, A.; Bhagooli, R.; Capper, R.; Cunning, R.; deVillert, A.; Haslun, J.A. Development of gene expression markers of acute heat-light stress in reef-building corals of the genus Porites. PLoS ONE 2011, 6, e26914. [CrossRef]

20. Kenkel, C.D.; Meyer, E.; Matz, M.V. Gene expression under chronic heat stress in populations of the mustard hill coral (Porites astreoides) from different thermal environments. Mol. Ecol. 2013, 22, 4322-4334. [CrossRef]

21. Haslun, J.A.; Strychar, K.B.; Buck, G.; Sammarco, P.W. Coral bleaching susceptibility is decreased following short-term (1-3 year) prior temperature exposure and evolutionary history. J. Mar. Biol. 2011, 2011, 1-13. [CrossRef]

22. Haslun, J.A.; Hauff, B.; Strychar, K.B.; Cervino, J.M. Decoupled seasonal stress as an indication of chronic stress and site dependent responses in Montastraea cavernosa and Porites astreoides inhabiting the Florida Reef Tract. Int. J. Mar. Sci. 2016, 6, 1-20. [CrossRef]

23. Kenkel, C.D.; Goodbody-Gringley, G.; Caillaud, D.; Davies, S.W.; Bartels, E.; Matz, M.V. Evidence for a host role in thermotolerance divergence between populations of the mustard hill coral (Porites astreoides) from different reef environments. Mol. Ecol. 2013, 22, 4335-4348. [CrossRef]

24. Guest, J.R.; Baird, A.H.; Maynard, J.A.; Muttaqin, E.; Edwards, A.J.; Campbell, S.J.; Yewdall, K.; Affendi, Y.A.; Chou, L.M. Contrasting patterns of coral bleaching susceptibility in 2010 suggest an adaptive response to thermal stress. PLoS ONE 2012, 7, e33353. [CrossRef]

25. Barshis, D.J.; Ladner, J.T.; Oliver, T.A.; Seneca, F.O.; Traylor-Knowles, N.; Palumbi, S.R. Genomic basis for coral resilience to climate change. Proc. Natl. Acad. Sci. USA 2013, 110, 1387-1392. [CrossRef]

26. Howells, E.J.; Beltran, V.H.; Larsen, N.W.; Bay, L.K.; Willis, B.L.; Van Oppen, M.J.H. Coral thermal tolerance shaped by local adaptation of photosymbionts. Nat. Clim. Chang. 2012, 2, 116-120. [CrossRef]

27. Middlebrook, R.; Hoegh-Guldberg, O.; Leggat, W. The effect of thermal history on the susceptibility of reef-building corals to thermal stress. J. Exp. Biol. 2008, 211, 1050-1056. [CrossRef] [PubMed]

28. Haslun, J.A.; Hauff-Salas, B.; Strychar, K.B.; Ostrom, P.; Cervino, J.M. Biotic stress contributes to seawater temperature induced stress in a site-specific manner for Porites asteroides. Mar. Biol. 2018, 165, 159-172. [CrossRef]

29. Vollmer, S.V.; Kline, D.I. Natural disease resistance in threatened staghorn corals. PLoS ONE 2008, 3, e3718. [CrossRef]

30. Campbell-Lendrum, D.H.; Pruss-Ustun, A.; Corvalan, C.F. How much disease could climate change cause? In Climate Change and Human Health—Risks and Responses; McMichael, A.J., Campbell-Lendrum, D.J., Corvalan, C.F., Ebi, K.L., Githeko, A., Scheraga, J.D., Woodward, A., Eds.; World Health Organization: Geneva, Switzerland; Elsevier Science: Amsterdam, The Netherlands, 2003; pp. 133-155. Available online: https: / / citeseerx.ist.psu.edu/viewdoc/download?doi=10.1.1.1041.1884\&rep=rep1\&type=pdf (accessed on 29 July 2021).

31. Rocklöv, J.; Dubrow, R. Climate change: An enduring challenge for vector-borne disease prevention and control. Nat. Immunol. 2020, 21, 479-483. [CrossRef] [PubMed]

32. Manzello, D.P.; Enochs, I.C.; Kolodziej, G.; Carlton, R. Coral growth patterns of Montastraea cavernosa and Porites astreoides in the Florida Keys: The importance of thermal stress and inimical waters. J. Exp. Mar. Biol. Ecol. 2015, 471, 198-207. [CrossRef] 
33. Baird, A.H.; Marshall, P.A. Mortality, growth and reproduction in scleractinian corals following bleaching on the Great Barrier Reef. Mar. Ecol. Prog. Ser. 2002, 237, 133-141. [CrossRef]

34. Gochfeld, D.J.; Olson, J.B.; Slattery, M. Colony versus population variation in susceptibility and resistance to dark spot syndrome in the Caribbean coral Siderastrea siderea. Dis. Aquat. Organ. 2006, 69, 53-65. [CrossRef]

35. Richardson, L.L.; Goldberg, W.M.; Carlton, R.G.; Halas, J.C. Coral disease outbreak in the Florida Keys: Plague Type II. Rev. Biol. Trop. 1998, 46, 187-198.

36. Oliver, T.A.; Palumbi, S.R. Do fluctuating temperature environments elevate coral thermal tolerance? Coral Reefs 2011, 30, 429-440. [CrossRef]

37. Fuess, L.E.; Pinzón, C.J.H.; Weil, E.; Grinshpon, R.D.; Mydlarz, L.D. Life or death: Disease-tolerant coral species activate autophagy following immune challenge. Proc. R. Soc. B Biol. Sci. 2017, 284, 20170771. [CrossRef] [PubMed]

38. Cervino, J.; Goreau, T.J.; Nagelkerken, I.; Smith, G.W.; Hayes, R. Yellow band and dark spot syndromes in Caribbean corals: Distribution, rate of spread, cytology, and effects on abundance and division rate of zooxanthellae. Hydrobiologia 2001, 460, 53-63. [CrossRef]

39. Bruckner, A.W.; Riegl, B. Yellow-band diseases. In Diseases in Coral; Woodley, C.M., Down, C.A., Bruckner, A.W., Porter, J., Sylvia, W., Galloway, B., Eds.; John Wiley and Sons Inc.: Hoboken, NJ, USA, 2015; pp. 376-386. ISBN 9781118828502. [CrossRef]

40. Subhan, B.; Arafat, D.; Rahmawati, F.; Dasmasela, Y.H.; Royhan, Q.M.; Madduppa, H.; Santoso, P.; Prabowo, B. Coral disease at Mansuar Island, Raja Ampat, Indonesia. IOP Conf. Ser. Earth Environ. Sci. 2020, 429, 012027. [CrossRef]

41. Côté, I.M.; Gill, J.A.; Gardner, T.A.; Watkinson, A.R. Measuring coral reef decline through meta-analyses. Philos. Trans. R. Soc. B. Biol. Sci. 2005, 360, 385-395. [CrossRef]

42. Bruno, J.F.; Sweatman, H.; Precht, W.F.; Selig, E.R.; Schutte, V.G.W. Assessing evidence of phase shifts from coral to macroalgal dominance on coral reefs. Ecology 2009, 90, 1478-1484. [CrossRef] [PubMed]

43. Moulding, A.L. Coral recruitment patterns in the Florida Keys. Rev. Biol. Trop. 2005, 53, 75-82.

44. Miller, M.W.; Weil, E.; Szmant, A.M. Coral recruitment and juvenile mortality as structuring factors for reef benthic communities in Biscayne National Park, USA. Coral Reefs 2000, 19, 115-123. [CrossRef]

45. Hauff, B.; Haslun, J.A.; Strychar, K.B.; Ostrom, P.; Cervino, J.M. Symbiont diversity of zooxanthellae (Symbiodinium spp.) in Porites astreoides and Montastraea cavernosa from a reciprocal transplant in the lower Florida Keys. Int. J. Biol. 2016, 8, 9-22. [CrossRef]

46. Hauff-Salas, B.; Haslun, J.A.; Strychar, K.B.; Ostrom, P.H.; Cervino, J.M. Site-specific variation in gene expression from Symbiodinium spp. associated with offshore and inshore Porites astreoides in the lower Florida Keys is lost with bleaching and disease stress. PLoS ONE 2017, 12,1-19. [CrossRef]

47. Fleige, S.; Pfaffl, M.W. RNA integrity and the effect on the real-time qRT-PCR performance. Mol. Asp. Med. 2006, 27, 126-139. [CrossRef]

48. Rozen, S.; Skaletsky, H.J. Primer3 on the WWW for general users and for biologist programmers. In Bioinformatics Methods and Protocols: Methods in Molecular Biology; Krawetz, S., Misener, S., Eds.; Humana Press: Totowa, NJ, USA, 2000 ; pp. 365-386. Available online: http:/ / sourceforge.net/projects / primer3/ (accessed on 29 July 2021).

49. Derveaux, S.; Vandesompele, J.; Hellemans, J. How to do successful gene expression analysis using real-time PCR. Methods 2010, 50, 227-230. [CrossRef] [PubMed]

50. Bagchi, A.; Herrup, E.A.; Warren, H.S.; Trigilio, J.; Shin, H.-S.; Valentine, C.; Hellman, J. MyD88-dependent and MyD88independent pathways in synergy, priming, and tolerance between TLR agonists. J. Immunol. 2007, 178, 1164-1171. [CrossRef] [PubMed]

51. Häcker, H.; Tseng, P.-H.; Karin, M. Expanding TRAF function: TRAF3 as a tri-faced immune regulator. Nat. Rev. Immunol. 2011, 11, 457-468. [CrossRef]

52. Rowley, A.F.; Powell, A. Invertebrate immune systems specific, quasi-specific, or nonspecific? J. Immunol. 2007, 179, 7209-7214. [CrossRef]

53. Medzhitov, R.; Janeway, C.A., Jr. Decoding the patterns of self and nonself by the innate immune system. Science 2002, 296, 298-300. [CrossRef] [PubMed]

54. Zhang, L.; Smit-McBride, Z.; Pan, X.; Rheinhardt, J.; Hershey, J.W.B. An oncogenic role for the phosphorylated h-subunit of human translation initiation factor eIF3. J. Biol. Chem. 2008, 283, 24047-24060. [CrossRef]

55. Muñoz, A.; Castellano, M.M. Regulation of translation initiation under abiotic stress conditions in plants: Is it a conserved or not so conserved process among eukaryotes? Comp. Funct. Genom. 2012, 2012, 406357. [CrossRef] [PubMed]

56. Singh, B.; Chauhan, H.; Khurana, J.P.; Khurana, P.; Singh, P. Evidence for the role of wheat eukaryotic translation initiation factor 3 subunit $\mathrm{g}$ (TaeIF3g) in abiotic stress tolerance. Gene 2013, 532, 177-185. [CrossRef]

57. Shima, F.; Okada, T.; Kido, M.; Sen, H.; Tanaka, Y.; Tamada, M.; Hu, C.D.; Yamawaki-Kataoka, Y.; Kariya, K.; Kataoka, T. Association of yeast adenylyl cyclase with cyclase-associated protein CAP forms a second Ras-binding site which mediates its Ras-dependent activation. Mol. Cell. Biol. 2000, 20, 26-33. [CrossRef] [PubMed]

58. Shima, F.; Yamawaki-Kataoka, Y.; Yanagihara, C.; Tamada, M.; Okada, T.; Kariya, K.; Kataoka, T. Effect of association with adenylyl cyclase-associated protein on the interaction of yeast adenylyl cyclase with Ras protein. Mol. Cell. Biol. 1997, 17, 1057-1064. [CrossRef]

59. Montminy, M. Transcriptional regulation by cyclic AMP. Annu. Rev. Biochem. 1997, 66, 807-822. [CrossRef] [PubMed] 
60. Serezani, C.H.; Ballinger, M.N.; Aronoff, D.M.; Peters-Golden, M. Cyclic AMP: Master regulator of innate immune cell function. Am. J. Respir. Cell. Mol. Biol. 2008, 39, 127-132. [CrossRef]

61. Matz, M.V.; Wright, R.M.; Scott, J.G. No control genes required: Bayesian analysis of qRT-PCR data. PLoS ONE 2013, 8, e71448. [CrossRef] [PubMed]

62. Livak, K.J.; Schmittgen, T.D. Analysis of relative gene expression data using real-time quantitative PCR and. Methods 2001, 25, 402-408. [CrossRef]

63. Strychar, K.B.; Sammarco, P.W. Exaptation in corals to high seawater temperatures: Low concentrations of apoptotic and necrotic cells in host coral tissue under bleaching conditions. J. Exp. Mar. Biol. Ecol. 2009, 369, 31-42. [CrossRef]

64. Sammarco, P.W.; Strychar, K.B. Effects of climate change/global warming on coral reefs: Exaptation in corals, evolution in zooxanthellae, and biogeographic shifts. Environ. BioIndic. 2009, 4, 9-45. [CrossRef]

65. Price, P.B.; Sowers, T. Temperature dependence of metabolic rates for microbial growth, maintenance, and survival. Proc. Natl. Acad. Sci. USA 2004, 101, 4631-4636. [CrossRef] [PubMed]

66. Abirami, G.; Radhakrishnan, M.; Kumaran, S.; Wilson, A. Impacts of global warming on marine microbial communities. Sci. Total Environ. 2021, 791, 147905. [CrossRef]

67. Bruno, J.F.; Selig, E.R.; Casey, K.S.; Page, C.A.; Willis, B.L.; Harvell, C.D.; Sweatman, H.; Melendy, A.M. Thermal stress and coral cover as drivers of coral disease outbreaks. PLoS Biol. 2007, 5, 1220-1227. [CrossRef]

68. Cerrano, C.; Bavestrello, G.; Bianchi, C.N.; Cattaneo-Vietti, R.; Bava, S.; Morganti, C.; Morri, C.; Picco, P.; Sara, G.; Schiaparelli, S.; et al. A catastrophic mass-mortality episode of gorgonians and other organisms in the Ligurian Sea (North-Western Mediterranean), summer 1999. Ecol. Lett. 2000, 3, 284-293. [CrossRef]

69. Sussman, M.; Loya, Y.; Fine, M.; Rosenberg, E. The marine fireworm Hermodice carunculata is a winter reservoir and spring-summer vector for the coral-bleaching pathogen Vibrio Shiloi. Environ. Microbiol. 2003, 5, 250-255. [CrossRef]

70. Gilbert, J.A.; Steele, J.A.; Caporaso, J.G.; Steinbrück, L.; Reeder, J.; Temperton, B.; Huse, S.; Huse, S.; McHardy, A.C.; Knight, R.; et al. Defining seasonal marine microbial community dynamics. ISME J. 2012, 6, 298-308. [CrossRef]

71. Fuhrman, J.A.; Cram, J.A.; Needham, D.M. Marine microbial community dynamics and their ecological interpretation. Nat. Rev. Microbiol. 2015, 13, 133-146. [CrossRef] [PubMed]

72. Cavicchioli, R.; Ripple, W.J.; Timmis, K.N.; Azam, F.; Bakken, R.R.; Baylis, M.; Behrenfeld, M.J.; Boetius, A.; Boyd, P.W.; Classen, A.T.; et al. Scientists' warning to humanity: Microorganisms and climate change. Nat. Rev. Microbiol. 2019, 17, 569-586. [CrossRef] [PubMed]

73. Kenkel, C.D.; Sheridan, C.; Leal, M.C.; Bhagooli, S.R.; Castillo, K.D.; Kurata, N.; McGinty, E.; Goulet, T.L.; Matz, M.V. Diagnostic gene expression of coral thermal stress. Mol. Ecol. Resour. 2014, 14, 667-678. [CrossRef]

74. Louis, D.Y.; Bhagooli, R.; Kenkel, C.D.; Baker, A.C.; Dyall, S.D. Gener expression biomarkers of heat stress in scleractinian corals: Promises and limitations. Comp. Biochem. Physiol. C. 2017, 191, 63-77. [CrossRef]

75. Gibbs, J.B.; Marshall, M.S. The ras oncogene-an important regulatory element in lower eucaryotic organisms. Microbiol. Rev. 1989, 53, 171-185. [CrossRef]

76. Kawecki, T.J.; Ebert, D. Conceptual issues in local adaptation. Ecol. Lett. 2004, 7, 1225-1241. [CrossRef]

77. Sammarco, P.W.; Andrews, J.C. Localized dispersal and recruitment in great barrier reef corals: The helix experiment. Science 1988, 239, 1422-1424. [CrossRef] [PubMed]

78. Sammarco, P.W.; Andrews, J.C. The Helix experiment: Differential localized dispersal and recruitment patterns in Great Barrier Reef corals. Limnol. Oceanogr. 1989, 34, 896-912. [CrossRef]

79. Sanford, E.; Kelly, M.W. Local adaptation in marine invertebrates. Annu. Rev. Mar. Sci. 2011, 3, 509-535. [CrossRef] [PubMed]

80. Moret, Y.; Siva-Jothy, M.T. Adaptive innate immunity? Responsive-mode prophylaxis in the mealworm beetle, Tenebrio molitor. Proc. Biol Sci. 2003, 270, 2475-2480. [CrossRef]

81. Armitage, S.A.O.; Thompson, J.J.W.; Rolff, J.; Siva-Jothy, M.T. Examining costs of induced and constitutive immune investment in Tenebrio molitor. J. Evol. Biol. 2003, 16, 1038-1044. [CrossRef]

82. Lochmiller, R.L.; Deerenberg, C. Trade-offs in evolutionary immunology: Just what is the cost of immunity? Oikos 2000, 88, 87-98. [CrossRef]

83. Porter, J.W.; Dustan, P.; Jaap, W.C.; Patterson, K.L.; Kosmynin, V.; Meier, O.W.; Patterson, M.E.; Parsons, M. Patterns of spread of coral disease in the Florida Keys. In The Ecology and Etiology of Newly Emerging Marine Diseases; Porter, J.W., Ed.; Springer: Dordrecht, The Netherlands, 2001; pp. 1-24. ISBN 978-94-017-3284-0. [CrossRef]

84. Sammarco, P.W.; Strychar, K.B. Ecological and evolutionary considerations regarding corals in a rapidly changing environment. In The Cnidaria, Past, Present and Future; Goffredo, S., Dubinsky, Z., Eds.; Springer International Publishing: Cham, Switzerland, 2016; pp. 553-573. ISBN 978-3319313030. [CrossRef]

85. Bay, R.A.; Rose, N.H.; Logan, C.A.; Palumbi, S.R. Genomic models predict successful coral adaptation if future ocean warming rates are reduced. Sci. Adv. 2017, 3, e1701413. [CrossRef]

86. Fine, M.; Hoegh-Guldberg, O.; Meroz-Fine, E.; Dove, S. Ecological changes over 90 years at Low Isles on the Great Barrier Reef. Nat. Commun. 2019, 10, 4409. [CrossRef] 